\title{
PANDANGAN HIDUP DAN SISTEM PENGETAHUAN LOKAL MASYARAKAT JAWA DI BALIK EKSPRESI GAYA BAHASA DALAM EMPAT KARYA SASTRA KI PADMASUSASTRA
}

\author{
Prasetyo Adi Wisnu Wibowo \\ Program Studi Sastra Daerah Fakultas Ilmu Budaya \\ Universitas Sebelas Maret Surakarta \\ Pos-el: prasetyoadiwisnuwibowo@yahoo.co.id
}

\begin{abstract}
Abstrak
Empat karya sastra Ki Padmasusastra mencerminkan pola pikir, pola pandang masyarakat Jawa terhadap Tuhan dan alam sekitarnya. Penelitian ini berusaha menemukan pola-pikir, pandangan dunia, pandangan hidup dan sistem pengetahuan lokal yang dimiliki $\mathrm{Ki}$ Padmasusastra sebagai bagian dari masyarakat Jawa di balik ekspresi bahasa Jawa yang dipergunakannya. Penelitian ini menggunakan metode kualitatif deskriptif..Ekspresi gaya bahasa yang digunakan dalam empat karya Ki Padmasusastra merupakan gambaran perilaku untuk mencapai kesejahteraan hidup yang tercermin dalam perilaku verbal, baik menyangkut pandangan hidup (way of life), pandangan dunia (world view), maupun pola-pikir yang tercermin dalam sistem pengetahuan (cognition system) masyarakatnya.
\end{abstract}

Kata kunci: gaya bahasa, pandangan hidup, karya sastra, Ki Padmasusastra

\section{LIFE PERSPECTIVE AND LOCAL KNOWLEDGE SYSTEM \\ OF JAVA SOCIETY BEHIND THE EXPRESSION OF LANGUAGE STYLES IN THE FOUR LITERARY WORKS OF KI PADMASUSASTRA}

\begin{abstract}
The four literary works of Ki Padmasusastra reflect the mindset and Javanese society's point of view of God and the nature.This research tries to find the pattern of thought, world view, view of life and local knowledge system of Ki Padmasusastra as part of Javanese society that reflected by Javanese expression. This research uses descriptive qualitative method. The expression of the language style used in the four literary works of Ki Padmasusastra is a description of behavior to achieve the welfare of life which is reflected in verbal behavior, whether it concerns with the way of life, the world view, and the pattern of thought that are reflected in the cognition system of the society.
\end{abstract}

Keywords: language style, view of life, literary works, Ki Padmasusastra

\section{PENDAHULUAN}

Ada fenomena bahwa ekspresi bahasa Jawa mencerminkan kearifan lokal beserta tuntutan kebutuhan hidup masyarakatnya. Gaya bahasa yang dipergunakan Ki Padmasusastra sebagai orang Jawa sangat terkait dengan pola pikir dan sistem pengetahuan yang dimiliki masyarakat Jawa secara kolektif. Bahasa dipahami bukan semata-mata berdiri secara linier sebagai rentetan bunyi, melainkan merupakan bagian dari ekspresi totalitas lahir batin masyarakat penuturnya berdasarkan konteks budaya yang dimiliki 
beserta dengan segala nilai-nilai ekspresi dalam hidupnya secara individual maupun secara kelompok. Melalui data yang berupa fakta kebahasaan dalam empat karya Ki Padmasusastra itu akan diperoleh dan ditafsirkan informasi-informasi penting mengenai sistem pengetahuan yang terkandung di dalamnya.

Subroto, et al. (2010) mengatakan bahwa masyarakat Jawa sering memakai bahasa-bahasa dalam bentuk-bentuk pasemon, ketidaklangsungan atau bersifat sirkuler 'tidak langsung' dalam berbahasa lebih disukai, dan penuh dengan makna simbolik. Ki Padmasusastra sebagai bagian dari masyarakat Jawa sering mempergunakan tuturan secara tidak langsung dengan memakai majas-majas. Ki Padmasusastra memakai gaya bahasa tidak hanya untuk kepentingan estetis, tetapi ketidaklangsungan berbahasa salah satunya dipakai sebagai sarana untuk menghindari konflik dan tidak menyinggung perasaan orang lain.

Pengertian kearifan lokal sebagai "perangkat" pengetahuan dan praktik-praktik yang dapat digunakan untuk menyelesaikan persoalan yang dihadapi dengan cara yang baik dan benar (Ahimsa, 2007: hlm. 17). Dengan demikian dapat diasumsikan bahwa di sana terdapat banyak hal menarik untuk dibahas secara ilmiah, terutama secara Etnolinguistik (anthropological linguistics) yang menaruh perhatian terhadap posisi bahasa dalam konteks sosial-budaya yang lebih luas untuk memajukan dan mempertahankan praktik-praktik budaya dan struktur sosial (Foley, 1997: 3).

Kajian Etnolinguistik tentang penggunaan gaya bahasa dalam empat karya sastra Ki Padmasusastra ini yaitu untuk mencermati fenomena ekspresi bahasa Jawa dalam adat-istiadat yang mencerminkan kearifan lokal mereka beserta tuntutan kebutuhan hidupnya. Di samping itu ingin menggambarkan perilaku yang digunakan untuk mencapai kesejahteraan hidup yang tercermin dalam perilaku verbal dan nonverbal, baik menyangkut pandangan hidup (way of life), pandangan dunia (world view), pola-pikir yang tercermin dalam sistem pengetahuan (cognition system) masyarakat Jawa.

Lebih lanjut Subroto (2010: 2) menjelaskan bahwa Etnolinguistik sebagai jenis linguistik yang kajiannya memfokuskan pada temuan-temuan yang akan disumbangkan dalam sistem kebudayaan seperti tatabahasa, kosakata dan pemahaman makna kontekstualnya. Pada intinya Etnolinguistik mencoba melakukan klasifikasi kognisi, pandangan hidup, pandangan dunia dan pola pikir bertolak dari data empiris kebahasaan dan sangat bertumpu pada dimensi leksikon beserta dimensi semantik bahasa dan budaya pemiliknya. Maka dari itu, bahasa sangat terkait dengan pola pikir dan sistem pengetahuan yang dimiliki masyarakat secara kolektif.

Adanya kajian Etnolinguistik ini diharapkan mampu menjelaskan "rasa" linguistik-antropologis yang ada (Fernandez, 2009: hlm. 19). "Rasa" dalam pemahaman sanepa bahasa Jawa ini menunjukkan bahwa bahasa dipahami bukan semata-mata berdiri secara linier sebagai rentetan bunyi, melainkan merupakan bagian dari ekspresi totalitas lahir-batin masyarakat penuturnya berdasarkan konteks budaya yang dimiliki beserta dengan segala nilai-nilai ekspresi dalam hidupnya secara individual maupun secara kelompok.

Penelitian ini bertujuan untuk a) mendeskripsikan penggunaan gaya bahasa dalam empat karya sastra $\mathrm{Ki}$ Padmasusastra yaitu Serat Prabangkara, Serat Rangsang Tuban, Serat Kandha Bumi dan Serat Kabar Angin, dan b) mendeskripsikan pandangan hidup masyarakat Jawa yang tercermin dalam penggunaan gaya bahasa empat karya $\mathrm{Ki}$ Padmasusastra yaitu Serat Prabangkara, Serat Rangsang Tuban, Serat Kandha Bumi dan Serat Kabar Angin. 


\section{METODE}

Penelitian ini adalah penelitian kualitatif deskriptif. Untuk membahas permasalahan dan mencapai tujuan penelitian, penelitian kualitatif deskriptif ini memakai strategi berpikir fenomenologis yang bersifat lentur dan terbuka serta menekankan analisisnya secara induktif dengan meletakkan data penelitian bukan sebagai alat pembuktian, tetapi sebagai modal dasar untuk memahami fakta-fakta yang ada.

Data dalam penelitian ini adalah berupa data kebahasaan yang berwujud kata-kata yang mengandung bunyi-bunyi tertentu.

Karya sastra Ki Padmasusastra yaitu Serat Prabangkara, Serat Rangsang Tuban, Serat Kandha Bumi dan Serat Kabar Angin. Sumber data berupa pustaka empat karya sastra berbentuk prosa dengan judul Serat Prabangkara, Serat Rangsang Tuban, Serat Kandha Bumi dan Serat Kabar Angin.

Pengumpulan data dalam penelitian ini ditempuh dengan langkah sebagai berikut. Dalam pengumpulan data, dilakukan dengan teknik content analysis yaitu pembacaan dan penghayatan sumber data utama. Pembacaan berulang-ulang dengan penuh intensitas dalam rangka memperoleh data yang tepat dan teliti. Adapun teknik analisis data menggunakan langkah-langkah reduksi data, sajian data dan penarikan kesimpulan.

\section{HASIL DAN PEMBAHASAN}

Pengarang menggunakan gaya bahasa, pelukisan biasa, ungkapan perangkaian diksi dan pengkalimatan secara lebih maksimal untuk melukiskan suasana, keadaan, karakter tokoh, tempat secara memikat dengan gaya bahasa. Di balik ekspresi bahasa yang berupa pepindahan dan metafora dalam empat karya sastra Ki Padmasusastra ini, sebenarnya tercermin pola pikir Ki Padmasusastra dalam memandang dunia (Padmasusastra, 1902, 1912, 1921, dan 1924), beserta segala isinya.
Adanya metafora dan simile karena orang Jawa senang pada bentuk-bentuk pasemon, penuh makna simbolik, ketidaklangsungan atau bersifat sirkuler 'tidak langsung'. Bahasa tidak bisa lepas dari kebudayaan karena bahasa merupakan hasil budaya suatu masyarakat yang kompleks dan aktif. Bahasa adalah aspek terpenting dalam mempelajari suatu kehidupan dan kebudayaan masyarakat.

\section{Kekhasan Penggunaan Gaya Bahasa Gaya Bahasa Simile/Pepindhan}

Data penggunaan 'simile, perumpamaan' dalam empat karya sastra Ki Padmasusastra, yaitu Serat Prabangkara, Serat Rangsang Tuban, Serat Kandha Bumi dan Serat Kabar Angin sebagai berikut.

\section{Dalam Serat Rangsang Tuban}

(1) ... wêninging jangga kawuryan sumorot apindha thathit, kocaking netra pindha lintang karainan, dhasar sêsinomipun barèh kados mêntas wungu saking sare, ... kicating pada gumêbyar pindha andaru lêlampah. Sang prabu awas ningali citranipun sang kadi Ratih, ....(SRT/8).

'... lehernya tampak bercahaya seperti kilat, kerling matanya seperti bintang kesiangan, rambut jidatnya terlihat tidak tertata seperti baru bangun dari tidur, ... jingkat langkahnya memancarkan sinar seperti ndaru berjalan. Sang prabu serius memperhatikan tingkah laku sang putri seperti Dewi Ratih,...'

Pepindhan 'simile' dalam data (1) di atas melukiskan keindahan leher sang putri apindha thathit 'seperti kilat', kerling matanya pindha lintang karainan 'seperti bintang kesiangan', sinom rambut dahinya kados mêntas wungu saking sare 'seperti baru dari bangun tidur', jingkat kakinya bersinar pindha andaru lêlampah 'seperti 
ndaru berjalan'. Kecantikan sang putri tersebut diibaratkan kadi Ratih 'seperti Dewi Ratih'.

(2) Galihipun sang pangeran kados rinujit, ... parêntuling luh kados intên rinonce...(SRT/15)

'Hati sang pangeran seperti diiris, ... tetes air mata seperti emas diuntai,...'

(3) ... cariyos lugu punika kados sêmining kêkajêngan, ... cariyos ingkang mawi sêsunggingan punika kados angganing pang ingkang katêrês, ...(SRT/22)

'... cerita polos ini seperti berseminya pepohonan, ... cerita dengan hiasan ini seperti batang yang dipotong, ...'

Data (2) menggambarkan kesedihan hati sang pangeran kados rinujit 'seperti diiris' dan tetes air mata kados intên rinonce 'seperti intan diuntai'. Dalam data (3) menggambarkan cerita kebenaran kados sêmining kêkajêngan 'seperti tumbuhnya pepohonan' dan cerita yang penuh rekaan kados angganing pang ingkang katêrês, alumipun katingal anyênyêngit 'seperti batang yang dipotong, layunya terlihat menyebalkan'.

Data (4) di bawah ini terdapat penggunaan simile yang beruntun terus menerus dan semakin memperindah makna tuturan. Malam yang mulai datang diibaratkan kados badhe angêlêm jagad 'seperti akan menenggelamkan dunia'. Tangis kesedihan dan keluarnya air mata sang pangeran kados turasan 'seperti buang air kecil'. Keindahan bulan purnama yang mulai muncul di puncak gunung kados wadananipun ingkang rayi 'seperti wajah Dewi Wresti', dan suara rusa di hutan seakan-akan kados panguwuh angaturi kondur dhatêng ing nagari Tuban 'seperti ingin mempersilahkan pulang ke negara Tuban'.
(4) ... pêpêtêng wiwit andhatêngi

kados badhe angêlêm jagad, ... waspa adrês kados turasan, ... aldaka sumorot kados wadananipun ingkang rayi, cumêngèring kidang alihan tilêm kados panguwuh angaturi kondur ...(SRT/49)

'... malam mulai mendatangi seperti akan menenggelamkan dunia, ... air mata keluar seperti buang air kecil, ... di puncak gunung bersinar seperti wajah Dewi Wresti, ringkikan rusa yang berganti tempat untuk tidur seperti ingin mempersilahkan pulang ...'

(5) ... sitarêsmi rêmu-rêmu kalingan ngrêgêmênging mega cêmêng apindha rêksasa kados angangkah badhe mangsa rêmbulan, lêpat tujunipun ingkang pindha pragalba, rêmbulan oncat dhawah ing mega pêthak, prabanipun sigar salong anyoroti siluk-siluking jêjurang, kados wayanganipun sawêr tapak angin, ebahing gêgodhongan katêmpuh ing angin kados pangawening astanipun satriya ingkang kawêlas asih, ...(SRT/98)

'... bulan mulai menampakkan sinar kuning terhalang mega hitam seperti raksasa seperti akan memakan bulan, syukurlah salah yang menyerupai raksasa, bulan bisa lari jatuh di mega putih, sinarnya pecah sebagian menerangi lubang-lubang lembah, seperti bayangan ular tapak angin, gerakan dedaunan diterjang angin seperti lambaian tangan kesatria yang selalu mengasihi...'

Data (5) di atas memperlihatkan suasana malam dengan mega yang tampak hitam digambarkan apindha rêksasa kados angangkah badhe mangsa rêmbulan 'seperti raksasa seperti akan memakan bulan'. Keadaan lembah yang dalam diibaratkan kados wayanganipun sawêr tapak angin 'seperti bayangan ular tapak 
angin'. Gerakan dedaunan yang terkena hembusan angin kados pangawening astanipun satriya ingkang kawêlas asih 'seperti lambaian tangan kesatria yang selalu mengasihi'.

\section{Dalam Serat Prabangkara}

(6) Rara Apyu, sariranipun singsêt ... apindha pradapaning angsoka, wadananipun mancorong pindha kartika mabangun...(SP/1).

'Rara Apyu badannya sintal ... seperti daun muda bunga angsoka, muka bersinar seperti bintang kejora sedang bangun...'

Pepindhan 'simile, perumpamaan' dalam data (6) di atas ditandai dengan kata pindha/apindha 'seperti'. Simile di atas digunakan untuk melukiskan kecantikan tubuh Rara Apyu dengan lambang perumpamaan apindha pradapaning angsoka 'seperti daun muda bunga angsoka' dan kecantikan wajah Rara Apyu pindha kartika mabangun 'seperti bintang kejora sedang bangun.

(7) ... tambinipun alongsor pindha taksaka mulêt padhas awaking sêndhang, suluripun tumali ing sela kados sinalang, toyanipun wêning pindha kaca ... amawa cahya pindha sambartaka anucup toya, dhawah ing sela gajah miring muncrat apindha wrêsti, ...(SP/22).

'... akarnya seperti ular melilit batu padas, akar yang menjuntai di batu seperti dirajut, air jernih seperti kaca, ... penuh cahaya seperti pengrusak minum air, jatuh di batu besar yang miring dan memancar seperti gajah...'

(8) Sang ayu ... kadi pangantèn ingkang mêntas pinurwa ing gati, riyêm-riyêm pindha kartika mabangun,...(SP/37).

'Sang ayu ... seperti pengantin selesai dinikahkan, terlihat bersinar seperti bintang kejora sedang bangun, ...'

Simile dalam data menggambarkan keindahan alam dengan kata perumpamaan pindha, kados, dan apindha 'seperti'. Untuk melukiskan akar pohon yang kuat dengan perumpamaan pindha taksaka mulêt padhas 'seperti ular melilit batu padas'. Untuk melukiskan akar yang menggelantung dengan perumpamaan kados sinalang seperti dirajut'. Kejernihan air diumpamakan pindha kaca 'seperti kaca'. Gemericik dan kejernihan air diumpamakan pindha sambartaka anucup toya 'pengrusak minum air'. Adapun batu besar diibaratkan apindha wrêsti 'seperti gajah'.

\section{Dalam Serat Kandha Bumi}

(9) ... susahing manahe ... kados upaminipun karêbahan rêdi, ...(SKB/11)

'... kesedihan hati ... diumpamakan seperti tertimpa gunung...'

Teks (9) di atas terdapat simile 'pepindhan'. Kesedihan hati Ki Jaga Mandhala dilambangkan dengan perumpamaan kados upaminipun karêbahan rêdi 'seperti tertimpa gunung'.

(10) ... kawulaning ratu kados upaminipun sarah munggèng lautan, ...(SKB/25)

'... bawahan raja seperti sampah berada di lautan, ...'

Data (10) menyatakan seorang rakyat jelata atau hamba raja tidak memiliki kewenangan apa-apa ibaratnya kados upaminipun sarah munggèng lautan, kombak-kombul sarta kentas dhatêng ing dharatan atas kawasananing alun 'seperti sampah berada di lautan, terombang-ambing dan bisa naik di daratan karena kekuasaan ombak'.

Data (11) diceritakan bahwa gerakan kain halus yang terkena angin 
pindha aluning sêgantên 'seperti ombak lautan'.

(11) Samirana ngidid nampêg maliyo malêmbung pindha aluning sêgantên, bara pindha roning pisang suwèk pating saluwir katêmpuh drêsing angin-angin, ...(SKB/38)

'Angin berhembus menerpa kain halus mengembang seperti ombak lautan, menyala seperti daun pisang sobek kecil-kecil terkena terpaan angin...'

\section{Dalam Serat Kabar Angin}

Penggunaan pepindhan 'simile, perumpamaan' dalam Serat Kabar Angin karya Ki Padmasusastra sebagai berikut.

(12) ... wadyabala andalêdêg kados toya mili saking êrong, ... ingkang rêkta pindha giri pawaka, ingkang krêsna pindha dhandhang rêraton, ingkang pita pindha podhang rêbut wowohan, ingkang seta pindha kuntul nêba, ingkang ijêm riyu-riyu pindha biruning langit, ....(SKA/5051)

'... bala tentaranya datang bersamaan seperti air mengalir dari lubang, $\ldots$ yang merah seperti gunung api, yang hitam seperti burung gagak bergerombol, yang bergaris seperti burung podang berebut buah-buahan, yang putih seperti kuntul menyebar, yang sangat hijau seperti birunya langit...'

Tuturan (12) juga menggunakan simile yaitu bala tentara yang dipimpin oleh sang patih kados toya mili saking êrong 'seperti air mengalir dari lubang', pakaian bala tentara yang berwarna merah diumpamakan pindha giri pawaka 'seperti gunung api', pakaian warna hitam pindha dhandhang rêraton 'seperti burung gagak bergerombol', pakaian warna bergaris pindha podhang rêbut wowohan 'seperti burung podang berebut buah-buahan, pakaian putih pindha kuntul nêba 'seperti burung kuntul menyebar', dan pakaian prajurit yang berwarna hijau pindha biruning langit 'seperti birunya langit'.

Data (13) menggambarkan kebahagiaan sang raja prasasat amanggih sêsotyaning bumi 'seperti menemukan intan bumi'.

(13) ... kawula sèwu bingah prasasat amanggih sêsotyaning bumi. ....(SKA/67)

'... saya sangat bahagia seperti menemukan intan bumi...'

\section{Gaya Bahasa Metafora}

\section{Dalam Serat Rangsang Tuban}

Data berikut memperlihatkan metafora yaitu angin yang berhembus seolah-olah bisa melakukan pekerjaan yang dilakukan oleh manusia yaitu pada tuturan samirana midit ambêkta gandaning sêkar 'angin berhembus membawa harum bunga'. Sinar bulan seolaholah bisa melakukan perbuatan membedah sela-sela dedaunan yang ditunjukkan dengan tuturan soroting rêmbulan ingkang ambêdhah lêlongkangan sêlaning godhong 'sinar bulan yang menyobek sela-sela daun'. Penggunaan metafora ini menjadikan tuturan semakin hidup.

(14) Samirana midit ambêkta gandaning sêkar saya adamêl rêncêming galih, ...(SRT/49)

'Angin berhembus membawa harum bunga semakin membuat kesedihan hati, ...'

(15) ... soroting rêmbulan ambêdhah lêlongkangan sêlaning godhong. ...(SRT/49)

'... sinar bulan menyobek sela-sela daun ...'

Data (16) berikut terdapat tuturan metafora yang menggambarkan usaha yang keras dan bersungguh-sungguh dengan tuturan tak rewangi suku jaja atêkên janggut 'saya niati berjalan dengan dada dan dagu sebagai tongkatnya'. 
(16) êndi kang kosênêngi, mêngko dakdhodhoge lawange, tak rewangi suku jaja atêkên janggut...(SRT/87)

'Mana yang kamu senangi, nanti saya ketuk pintunya, saya niati berjalan dengan dada dan dagu sebagai tongkatnya...'

Data (17) memperlihatkan seorang putri yang telah diperkosa seorang laki-laki diungkapkan dengan tuturan metaforik yaitu sariraning sêkar ingkang taksih kudhup rinodapaksa kinisêp dening kruraning bêrmara 'bunga yang masih belum mekar dipaksa dan dihisap oleh kebengisan kumbang'. Putri disamakan dengan sebuah sêkar 'bunga' dan seorang laki-laki disamakan dengan seekor bêrmara 'kumbang' yang telah memaksa menghisap bunga.

(17) ... amargi sariraning sêkar ingkang taksih kudhup rinodapaksa kinisêp dening kruraning bêrmara ....(SRT/53)

'... sebab bunga yang masih belum mekar dipaksa dan dihisap oleh kebengisan kumbang...'

Data (18) terdapat penggunaan metafora untuk mengungkapkan hal yang abstrak. Oleh karena itu pemanfaatan metafora dapat membantu untuk menghayati sebagai sesuatu yang konkret. Konsep ketaatan manusia kepada Tuhan diungkapkan dengan tuturan panunggaling kawula Gusti, sumêrêp ing sangkan paran 'bersatunya manusia dengan Tuhan, mengerti dari mana berasal dan ke mana tujuan'. Ilmu mengenai kebenaran hakekat keberadaan Tuhan ini sangat sesuai jika diungkapkan dengan tuturan ngèlmi kasampurnan 'ilmu kesempurnaan'. Manusia hidup harus mengerti sangkan paran 'dari mana berasal dan ke mana tujuan hidup'.

(18) ... Kyai Agêng Wulusan ... tinetesan ing ngèlmi kasampurnan, panunggaling kawula Gusti, sumêrêp ing sangkan paran,.... (SRT/61)

‘... Kyai Ageng Wulusan ... diberi ilmu kesempurnaan bersatunya manusia dengan Tuhan, mengerti darimana berasal dan ke mana tujuan...'

(19) ... kangge panggêsangan salêbêtipun matiraga, sabên dalu botên towong wontên ing paoman ....(SRT/96)

'Sang raja setiap hari pekerjaannya hanya menanam palawija kentang jagung, cantel, untuk hidup selama mematikan badan, setiap malam tidak pernah lupa di tempat pemujaan ...'

Data (19) di atas terdapat tuturan metaforik yaitu matiraga 'mematikan raga'. Maksud tuturan ini adalah bahwa manusia harus mampu mengendalikan hawa nafsu selagi masih hidup atau dengan istilah mematikan raga terhadap godaan nafsu di dunia, seperti terlalu banyak makan, tidur, seks dan sebagainya.

\section{Dalam Serat Prabangkara}

(20) ... wit cêmara kang kumrisik kabaratan kang anêksèni marang prasêtyaku ... ing ngriku têmpuking katrêsnan. ...(SP/5)

'Ketahuilah pangeran: aku tidak akan menikah sampai mati jika tidak mendapat kamu, pohon cemara yang berisik terkena angin yang menyaksikan kesetiaanku, kemarilah kamu saya peluk. Sang pangeran gemetar, di sana bertemunya kasih sayang...'

Data (20) terdapat metafora yaitu pohon cemara seolah-olah bisa bersaksi atas kesetiaan sang pangeran kepada sang putri atau dituturkan wit cêmara kang kumrisik kabaratan kang anêksèni marang prasêtyaku iki 'pohon cemara yang berisik terkena angin yang menyaksikan kesetiaanku'. 
Di bawah ini terdapat penggunaan metafora (data 21) dengan tuturan amêngakakên lawang suka, nginêbakên kori sungkawa 'membukakan pintu kebahagiaan, dan menutup pintu kesedihan'. Kebahagiaan dan kesedihan dimetaforikkan memiliki sebuah pintu. Jika kita menginginkan kebahagiaan maka harus amêngakakên lawang suka 'membukakan pintu kebahagiaan', dan jika ingin menjauhi dari kesengsaraan maka harus nginêbakên kori sungkawa 'kemenutup pintu kesedihan'.

(21) Sang nata lajêng jêngkar ngadhaton,... amêngakakên lawang suka, nginêbakên kori sungkawa. (SP/74)

'Sang raja segera pergi dari keraton, ... membukakan pintu kebahagiaan, dan menutup pintu kesedihan...'

\section{Dalam Serat Kandha Bumi}

(22) Kacariyos Radèn Sapartitala, sanadyan kapati brata tilar dhahar tilar guling, ....(SKB/15)

'Diceritakan Raden Sapartitala, walau melakukan tapa mencegah makan mencegah guling, ...'

Data (22) menyajikan suatu konsep bagaimana mengendalikan hawa nafsu agar selamat di dunia dan di akherat sangat sesuai diungkapkan dengan tuturan tilar dhahar tilar guling 'meninggalkan makan meninggalkan tidur' juga merupakan tuturan metaforik bahwa manusia hidup sebaiknya harus bisa mengendalikan nafsu yaitu makan dan tidur atau nafsu seks.

\section{Dalam Serat Kabar Angin}

(23) Sumiliring maruta manda ambêkta gandaning sêkar kumuning ing pasarean, amêmungu rujiting galihipun sang nata,... (SKA/4)

'Hembusan angin sepoi-sepoi membawa keharuman bunga kemuning di tempat pemakaman, membangunkan kesedihan hati sang raja...'
Data di atas memperlihatkan penggunaan gaya bahasa metafora. Hembusan angin seolah-olah mampu melakukan perbuatan ambêkta gandaning sêkar kumuning 'membawa keharuman bunga kumuning'. Tuturan masih dilanjutkan dengan gaya bahasa metafora yaitu hembusan angin sepoi-sepoi seakan-akan mampu melakukan tindakan seperti tindakan yang dilakukan manusia yaitu amêmungu rujiting galihipun sang nata 'membangunkan kesedihan hati sang raja'.

Penggunaan metafora dalam karya sastra tidak sekedar didorong oleh adanya fungsi estetika. Apabila bahasa sehari-hari tidak cukup untuk mengungkapkan kemampuan jiwa, maka metafora menjadi alat yang tepat untuk menyatakan 1) pikiran yang tersemayamkan jauh di seberang pengalaman, 2) konsep yang abstrak, 3) gejala (alam atau kemanusiaan yang belum pernah dialami, dan 4) pikiranpikiran yang tidak dapat dihayati.

(24) ... sang nata lajêng nungku
muja samadi angêningakên cipta,
nutupi babahan nawa sanga, pêjah
salêbêting gêsang....(SKA/4)
'Setelah tengah malam tiba sang raja
segera melakukan semadi meng-
heningkan cipta, menutup sembilan
lubang, mati selagi hidup...'

Data (24) terdapat penggunaan metafora dan dibuktikan dengan tuturan nutupi babahan nawa sanga, pêjah salêbêting gêsang 'menutup sembilan lubang, mati selagi hidup'. Metafora ini mengandung maksud bahwa manusia harus bisa menahan hawa nafsu yang ditimbulkan oleh sembilan lubang dalam tubuh manusia tatkala masih hidup. Dengan hati yang sabar, selalu mengendalikan hawa nafsu, maka akan terhindar dari perbuatan yang tidak baik. Angkara murka akan menyingkir dengan sendirinya.

Data (25) terdapat pemanfaatan metafora yang digunakan untuk mengung- 
kapkan konsep raja yang adil. Raja yang paramarta 'baik budinya' bisa paring usada ing karogan, paring boga ing kalapan, paring têkên ing kalunyon 'memberi pengobatan di saat sakit, memberi makan di saat kelaparan, memberi tongkat di saat terpeleset'. Adapun data (26) terdapat tuturan metaforik yaitu gilusi, janma tan kêna ingina. Tuturan ini sangat metaforik yang mengandung maksud bahwa setiap manusia sebenarnya tidak boleh menghina orang yang rendah. Diibaratkan seekor cacing tidak akan mampu naik sampai ke puncak gunung.

(25) Dhuh gusti ratu kêkasihing Allah ingkang misuwur ambêk paramarta paring usada ing karogan, paring boga ing kalapan, paring têkên ing kalunyon, ....(SKA/179)

'Duh gusti raja kekasih Tuhan, yang terkenal baik budinya memberi pengobatan di saat sakit, memberi makan di saat kelaparan, memberi tongkat di saat terpeleset, ...'

(26) ... ewadene badhe kacoba kapriksa mênggahing kasagêdanipun, paribasanipun wontên: giri lusi, janma tan kêna ingina , ....(SKA/183)

'... tetapi masih dicoba kepandaiannya, seperti peribahasa: gunung dan cacing, manusia tidak boleh dihina,...'

\section{Pandangan Hidup dan Sistem Pengetahuan Lokal Masyarakat Jawa Di Balik Gaya Bahasa dalam Empat Karya Sastra Ki Padmasusastra}

Empat karya Ki Padmasusastra sering diwarnai dengan tuturan-tuturan yang menggunakan gaya bahasa pepindhan /simile maupun metafora. Pepindhan 'simile, perumpamaan' ini ditandai dengan kata pindha, apindha, kadya, kados, kadi, kaya, prasasat, upama, umpama 'seperti'. Di balik ekspresi bahasa yang berupa pepindhan dan metafora dalam empat karya sastra Ki Padmasusastra ini, sebenarnya tercermin pola pikir $\mathrm{Ki}$ Padmasusastra dalam memandang dunia, beserta segala isinya.

Bahasa tidak bisa lepas dari kebuayaan karena bahasa merupakan hasil budaya suatu masyarakat yang kompleks dan aktif. Bahasa adalah aspek terpenting dalam mempelajari suatu kehidupan dan kebudayaan masyarakat.

Pemanfaatan simile dalam Serat Rangsang Tuban sebagai berikut.

(27) sariranipun katingal pindha ulam kalêbêt ing jala, mênthar kados sêkar mlathi, baludaging prêmbayun kados anjêbolakên kasêmêkan ....(SRT/30).

'Badannya terlihat seperti ikan masuk ke dalam jala, melebar seperti bunga melati, buah dadanya besar seakan-akan merusakkan kain penutup dada...'

Data di atas memperlihatkan penggunaan pepindhan yaitu pada tuturan baludaging prêmbayun kados anjêbolakên kasêmêkan 'buah dadanya besar seakanakan merusakkan kain penutup dada'.

(28) Rara Apyu, sariranipun singsêt ... apindha pradapaning angsoka, wadananipun mancorong pindha kartika mabangun...(SP/1).

'Rara Apyu badannya sintal ... seperti daun muda bunga angsoka, muka bersinar seperti bintang kejora sedang bangun...'

Pepindhan 'simile, perumpamaan' dalam data (28) di atas ditandai dengan kata pindha/apindha 'seperti'. Simile di atas digunakan untuk melukiskan kecantikan tubuh Rara Apyu dengan lambang perumpamaan apindha pradapaning angsoka 'seperti daun muda bunga angsoka' dan kecantikan wajah Rara Apyu pindha kartika mabangun 'seperti bintang kejora sedang bangun. 
(29) Sang Nata kasabêt ing antêngipun sang pindha Ratih...(SKB/39)

'Sang raja terkena pesona kewibawaan puteri seperti Dewi Ratih...'

(30) ... botên têdhas tapak paluning pandhe sisaning gurinda, sarta kawruh kridhaning praja, pangrèhipun dhatêng bala tantra, rumusaking ripu dibya sumusuping byuha kalawêrit, widagda sadaya, ..., brengos capang ngombak pindha sarpa tapak angin naut mamangsan, pantês trahing winani, sinêmbuh bantêr tapa brata ... kinudang krama satriya, marma winêlêg ing kramaniti. ...(SKB/15).

'... kebal senjata dan ilmu pemerintahan, cara memimpin bala tentara, merusak musuh sakti, pandai semua, ... kumis mengombak seperti ular tapak angin memakan mangsa, pantas keturunan orang pandai, dan disertai tapa brata... dicita-citakan menjadi kesatria, maka selalu diberi ajaran mengenai kesusilaan wanita, ...'

Bentuk-bentuk tuturan di atas merepresentasikan pandangan Ki Padmasusastra sebagai orang Jawa pada jaman itu. Bahasa merepresentasikan bahwa persepsi masyarakat dalam memandang perempuan telah mendapat perhatian yang besar. Perempuan mendapat acuan yang berbeda berdasarkan status sosial yang disandangnya. Penampilan fisik juga merupakan aspek yang penting bagi perempuan maupun laki-laki. Melalui gaya bahasa simile dalam rangka mengungkapkan sosok seorang wanita maupun laki-laki tersebut dapat diketahui bahwa masyarakat Jawa pada saat itu telah mengkonstruksi perbedaan gender antara perempuan dan laki-laki. Di satu sisi, Ki Padmasusastra ingin merubah adanya hegemoni kekuasaan mengenai kaum wanita.
(31) ... lare kêkalih winimbasara wontên ing pratapan, dinusan ing toya gege enggal agêng, kalis ing sêsakit, kalajun agêngipun, sasampunipun wanci ngumuripun pinrêtêk ing piwulang ... dhasar limpad ing panggraita sagêd ngêmpakakên dugi prayogi, ...(SKB/14).

'... dua anak dididik di pertapaan, dimandikan dengan air untuk memandikan bayi cepat besar, jauh dari sesakit, cepat besar dan ketika sudah saatnya diberi pelajaran ... sungguh pandai dan bisa memilih benar dan salah,...'

Ki Padmasusastra merasa bahwa wanita pada saat itu sulit menikmati pendidikan yang setara dengan kaum lakilaki. Dalam budaya Jawa, seorang gadis harus berperilaku sesuai dengan status biologis yang disandangnya. Seorang gadis yang menginjak remaja mulai kehilangan kebebasannya. Perilaku perempuan juga harus disesuaikan dengan status sosialnya. Seseorang yang berperilaku tidak sesuai dengan kodratnya akan dianggap melanggar tatanan. Hal ini dianggap tidak sesuai dengan adat yang terkonstruksi pada zaman itu, yaitu tidak tahu sopan santun, berani. Akan tetapi, Ki Padmasusastra mampu merubah pandangan yang demikian yang diekspresikan melalui gayagaya bahasa yang indah. Adanya ekspresi berupa simile atau pepindhan tersebut merupakan cerminan simbol pemberontakan terhadap hegemoni kekuasaan. Tuturan tersebut merupakan cerminan dari sikap pemberani $\mathrm{Ki}$ Padmasusastra terhadap kaum penguasa dan masyarakat.

Metafora dan simile sering dipergunakan dalam karya sastra karena orang Jawa senang pada bentuk-bentuk pasemon, penuh makna simbolik, ketidaklangsungan atau bersifat sirkuler 'tidak langsung' dalam. 
(34) Kacariyos Radèn Sapartitala, sanadyan kapati brata tilar dhahar tilar guling, ....(SKB/15)

'Diceritakan Raden Sapartitala, walau melakukan tapa mencegah makan mencegah guling, ...'

Data (34) memperlihatkan suatu konsep bagaimana mengendalikan hawa nafsu agar selamat di dunia dan di akherat sangat sesuai diungkapkan dengan tuturan tilar dhahar tilar guling 'meninggalkan makan meninggalkan tidur' juga merupakan tuturan metaforik bahwa manusia hidup sebaiknya harus bisa mengendalikan nafsu yaitu makan dan tidur atau nafsu seks.

(35) ... sang nata lajêng nungku muja samadi angêningakên cipta, nutupi babahan nawa sanga, pêjah salêbêting gêsang....(SKA/4)

'Setelah tengah malam tiba sang raja segera melakukan semadi mengheningkan cipta, menutup sembilan lubang, mati selagi hidup...'

Data (35) memperlihatkan penggunaan metafora dan dibuktikan dengan tuturan nutupi babahan nawa sanga, pêjah salêbêting gêsang 'menutup sembilan lubang, mati selagi hidup'. Metafora ini mengandung maksud bahwa manusia harus bisa menahan hawa nafsu yang ditimbulkan oleh sembilan lubang dalam tubuh manusia tatkala masih hidup. Dengan hati yang sabar, selalu mengendalikan hawa nafsu, maka akan terhindar dari perbuatan yang tidak baik. Angkara murka akan menyingkir dengan sendirinya.

Ekspresi bahasa yang diwarnai penggunaan gaya bahasa metafora ini mempresentasikan bahwa Ki Padmasusastra dalam mengungkapkan sesuatu menyukai ketidaklangsungan, penuh pasemon. Gaya bertutur tidak langsung ini mencerminkan ciri khas kepribadian masyarakat Jawa. Dalam rangka menghindari konflik atau menghaluskan tuturan, maka memerlukan bantuan tuturan-tuturan yang metaforis. Kehidupan religiusitas $\mathrm{Ki}$ Padmasusastra sebagai seorang kejawen tercermin di dalam karya sastranya yang sebenarnya menunjukkan pola pikirnya.

(36) tapake kontul anglayang / manuk mibêr muluk ngungkuli langit / kalawan gigiring punglu / kuda ngrab ing pandêngan / wêkasaning langit lan jaladri agung / tanggal pisan kapurnaman / sêntèg pisan anigasi // (SRT/65).

'Bekas telapak burung kontul yang terbang / burung berkeliaran terbang melebihi langit / dan bagian pinggir peluru / kuda menepak di depan penglihatan / akhir langit dan samudera luas / tanggal satu bulan purnama / akhirnya menemui kematian //'

Teks dalam tembang Pangkur di atas sebenarnya ajaran kejawen yang sangat tinggi nilai filosofisnya. Ada ungkapan Jawa golekana tapaking kontul nglayang 'carilah tapak burung kontul yang terbang', golekana gigiring punglu 'carilah bagian pinggir dari peluru'. Teks tersebut digunakan untuk mengajarkan bahwa keberadaan Tuhan merupakan sesuatu yang sulit untuk dijelaskan, akan tetapi manusia percaya bahwa Tuhan itu ada.

Kehidupan beliau sejak kecil dan kepercayaan yang kuat pada religi Jawa sangat mempengaruhi isi karya sastranya. Dalam teks di atas menyebutkan bahwa sesuatu yang dicari itu adalah tapak kontul nglayang (bekas burung terbang), gigir panglu (pinggir dari peluru), wekasaning langit lan jaladri agung (batas cakrawala dan lautan luas), yang merupakan sesuatu yang tidak tergambarkan atau tidak dapat disepertikan yang dalam bahasa Jawa tan kena kinaya ngapa". Hakekat Tuhan adalah sebuah kekosongan, atau suwung, Kekosongan adalah sesuatu yang ada tetapi tak tergambarkan. Itulah konsep keberada- 
an Tuhan yang diajarkan Ki Padmasusastra melalui tokoh Kyai Ageng Wulusan kepada Raden Udakawimba dalam bentuk ekspresi bahasa yang metaforis. Pola pikir jaman sekarang memang sulit dimengerti. Mengapa pitutur saja disamarkan seperti teka-teki yang ujung-ujungnya malah membuat bingung. Orang tua Jawa memberi pitutur sering tidak langsung tanpa penjelasan karena memang Jawa panggonane semu.

\section{SIMPULAN}

Penggunaan metafora erat kaitannya dengan pola pikir dan pandangan hidup $\mathrm{Ki}$ Padmasusastra antara lain nutupi babahan hawa sanga 'menutup sembilan lubang' dan pêjah salêbêting gêsang 'mati selagi masih hidup'. Banyak ajaran-ajaran Jawa yang baik dan disampaikan oleh $\mathrm{Ki}$ Padmasusastra secara metaforik. Hal ini sejalan dengan Tarrayo yang mengatakan bahwa pengkajian mengenai gaya bahasa dapat diungkapkan mengenai implikasi pedagogis. Ajaran Jawa yang penuh muatan moral sangat sesuai jika diungkapkan dengan gaya bahasa simile dan metafora.

Gaya bertutur tidak langsung ini mencerminkan ciri khas kepribadian masyarakat Jawa. Dalam rangka menghindari konflik atau menghaluskan tuturan, maka memerlukan bantuan tuturan-tuturan yang metaforis. Ajaran Jawa sering disamarkan dengan metafora-metafora karena memang Jawa panggonane semu 'Jawa tempat/penuh dengan perlambang'. Setiap orang diharapkan bisa menemukan intisari dengan kepekaannya masingmasing.

Saran dalam tulisan ini marilah mempelajari falsafah-falsafah hidup masyarakat Jawa yang banyak memiliki kandungan local genius, local wisdom, maupun local culture untuk membentengi pengaruh asing yang tidak baik masuk ke tanah air. Nilai-nilai yang terkandung dalam naskah-naskah lama dapat dijadikan sebagai salah satu alat untuk lebih memiliki jiwa yang berkarakter.

\section{DAFTAR RUJUKAN}

Ahimsa-Putra, Heddy Shri. 2007. "Ilmuwan Budaya dan Revitalisasi Kearifan Lokal. Tantangan Teoretis dan Metodologis". Pidato Ilmiah Dies Natalis FIB UGM ke 62 di Yogyakarta. Yogyakarta: Gadjah Mada University Press.

Subroto, Edi D . 2010. "Etnolinguistik". Surakarta: Program Pascasarjana Universitas Sebelas Maret.

Foley, W. A. 1997. Anthropological Linguistics An Introduction. University of Sydney: Blackwell Publishers.

Fernandez, Inyo Yos. 2009. "Keanekaragaman Bahasa Kerabat dan Kearifan Lokal Komunitas Subetnik Dayak di Kabupaten Kutai Barat, Kalimantan Timur". Artikel dimuat dalam Medan Bahasa. Jurnal Ilmiah. Departemen Diknas. Sekretaris Jenderal Pusat Bahasa. Balai Bahasa Surabaya, ISSBN 1907-1787.

Padmasusastra. 1902. Serat Kabar Angin. Surakarta: Vogel van der Heyde \& Co. Surakarta.

Padmasusastra. 1912. Serat Rangsang Tuban. Surakarta: n.v. Budiutama.

Padmasusastra. 1921. Serat Prabangkara. Kediri: Tan Khoen Swie.

Padmasusastra. 1924. Serat Kandha Bumi. Kediri: Tan Khoen Swie.

\section{UCAPAN TERMA KASIH}

Tderima kasih dan penghargaan yang setinggi-tingginya penulis sampaikan kepada tim penyunting Jurnal Lokabasa atas dimuatnya artikel ini. 